\section{Sauna builder's asthma caused by obeche (Triplochiton scleroxylon) dust}

\author{
Kari Reijula, Veikko Kujala, \\ Jari Latvala
}

\begin{abstract}
Two carpenters developed rhinitis, conjunctivitis, bronchial wheezing, and dyspnoea while using obeche (Triplochiton scleroxylon, African maple) at their work while they built saunas. Skin prick tests showed an immediate reaction, specific IgE to obeche was detected in their serum, and bronchial provocation test with obeche gave an immediate reaction with decrease of $F E V_{1}$ and PEF values. The symptoms disappeared after avoiding the use of obeche. Obeche may cause a health hazard to carpenters who are exposed to this dust and who may develop allergic symptoms after the exposure.
\end{abstract}

(Thorax 1994;49:622-623)

Obeche (Triplochiton scleroxylon) has been widely used as a moisture and heat resistant material in saunas throughout Scandinavia. Carpenters who build saunas are exposed to the dust of obeche during sawing. Obeche is also called African maple, whitewood, samba, and wawa. It is imported to Europe in large quantities for use in window frames, blackboards, framing, plywood, boxes, and planks.

In recent years obeche induced respiratory disorders have been encountered with increasing frequency. ${ }^{12}$

\section{Oulu Regional}

Institute of

Occupational Health

and Department of

Occupational

Medicine, Oulu

University Central

Hospital, Oulu,

Finland

K Reijula

V Kujala

J Latvala

Reprint requests to:

Dr K E Reijula, VA Medical

Center, Allergy Research

$151,5000 \mathrm{~W}$ National

Avenue, Milwaukee,

Wisconsin 53295-1000

USA.

Received 25 February 1993

Returned to authors

Returned to
10 June 1993

10 June 1993

5 August 1993

5 August 1993
Accepted for publication

Accepted for pu

\section{Case reports}

PATIENT 1

A 30 year old male carpenter developed atopic dermatitis, rhinitis, and dyspnoea in September 1990. Since 1985 he had worked as a full time construction worker repairing saunas and bathrooms. The patient had suffered from atopic dermatitis and had smoked 20 cigarettes a day for 15 years. Skin prick tests in 1979 and 1988 caused an immediate weal and flare reaction to cat and cow epithelium, house dust mite ( $D$ pteronyssinus), tree pollens, and a mixture of moulds, while skin prick tests with oak and pine were negative.

In 1990 he developed rhinorrhoea and nasal congestion, then cough and wheeze immediately after sawing obeche. The symptoms disappeared at weekends. On examination in September 1990 chest auscultation was normal. The leucocyte count was $9.9 \times 10^{9} / 1$ with $2 \%$ eosinophils; total serum IgE was $2560 \mathrm{IU} / \mathrm{ml}$ and specific IgE to obeche was $17.5 \mathrm{IU} / \mathrm{ml}$. A skin prick test with an inhouse obeche test reagent ( $2 \mathrm{mg}$ obeche dust in $50 \mu \mathrm{l}$ PBS, $\mathrm{pH} 7 \cdot 4$, at $22^{\circ} \mathrm{C}$ ) showed an immediate weal and flare reaction $12 \mathrm{~mm}$ in diameter. A skin prick test with the same obeche test reagent in 10 control individuals without any allergic symptoms was negative. The chest radiograph was normal. The FVC and $\mathrm{FEV}_{1}$ were greater than $80 \%$ predicted. ${ }^{3}$ No evidence of bronchial hyperreactivity was detected by metacholine provocation testing.

Bronchial provocation with the patient inhaling obeche sawing dust in an exposure chamber for five minutes was performed (fig 1). After 20 minutes the patient developed rhinorrhoea, bronchial wheezing, and dyspnoea. On auscultation expiratory wheezing could be detected. The FEV decreased from $^{2}$ 3.91 to $2.51(35 \%)$ and PEF values changed from 540 to $3001 / \min (45 \%)$. A control test with lactose did not show any changes in either FEV , or PEF values.

Occupational asthma due to obeche was diagnosed. The patient continued to work as a carpenter but began to use a ventilatory mask and avoided using obeche at work. His symptoms disappeared and he remained asymptomatic except once when he used an electric saw which had been used by another carpenter to cut obeche.

\section{PATIENT 2}

A 26 year old carpenter presented with dyspnoea. He had worked as a carpenter specialising in building and repairing saunas and bathrooms since 1986 . He had a history of atopic dermatitis but no history of allergic respiratory disorders. He had smoked 15-20 cigarettes a day for eight years.

In 1991 the patient developed rhinorrhoea and dyspnoea a few hours after he had been sawing obeche material. After a few days, severe dyspnoea occurred immediately after using obeche. Auscultation revealed wheezing which recovered after administration of a $\beta$ sympathomimetic drug. He subsequently continued his work and developed severe dys-

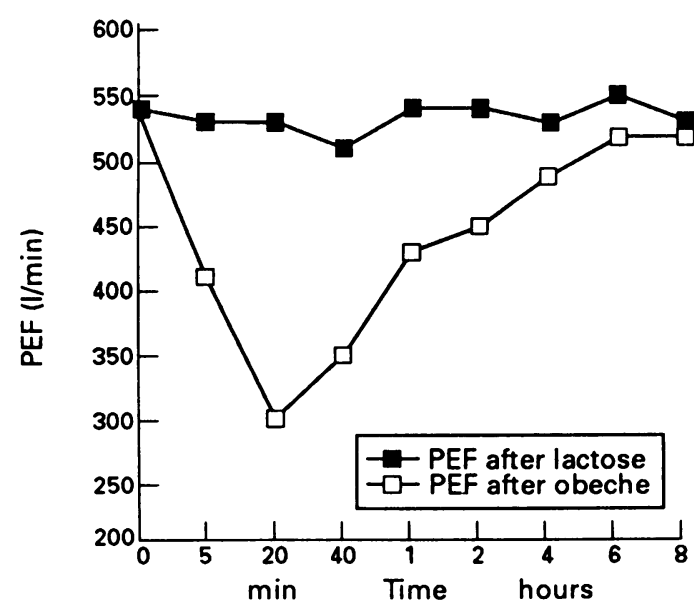

Figure 1 Peak expiratory flow (PEF) values of patient 1 after obeche and lactose provocation tests. 
pnoea twice more before further investigations.

In May 1991 whilst asymptomatic and clinically well the total leucocyte count was $4.4 \times 10^{9} / 1$ with $1 \%$ eosinophils. Total serum $\mathrm{IgE}$ was $7 \mathrm{IU} / \mathrm{ml}$ and specific IgE to obeche was $0.3 \mathrm{IU} / \mathrm{ml}$. No skin prick test reactions were detected to common inhalant allergens, whereas the test for obeche gave a weal and flare reaction $6 \mathrm{~mm}$ in diameter. The chest radiograph was normal. The FVC was 5.311 (95\% predicted) and the FEV $13.711(77 \%)$. Bronchial hyperreactivity was observed in a histamine provocation test, with the $\mathrm{FEV}_{1}$ decreasing from 3.85 to $3.201(17 \%)$ after $400 \mu \mathrm{g}$ histamine. In a bronchial provocation test (fig 2) the patient inhaled obeche dust for five minutes. After 20 minutes the patient developed cough, dyspnoea, and wheeze. PEF values decreased from 575 to $380 \mathrm{l} / \mathrm{min}(35 \%)$ and $\mathrm{FEV}_{1}$ from 3.7 to $2.91(22 \%)$. After inhaling $\beta$-sympathomimetic medication $\mathrm{FEV}_{1}$ recovered to 3.81 . When a control provocation test was performed using lactose no change in $\mathrm{FEV}_{1}$ or PEF values occurred.

After the diagnosis of obeche induced asthma an inhaled corticosteroid was added to his medication. He avoided using obeche and

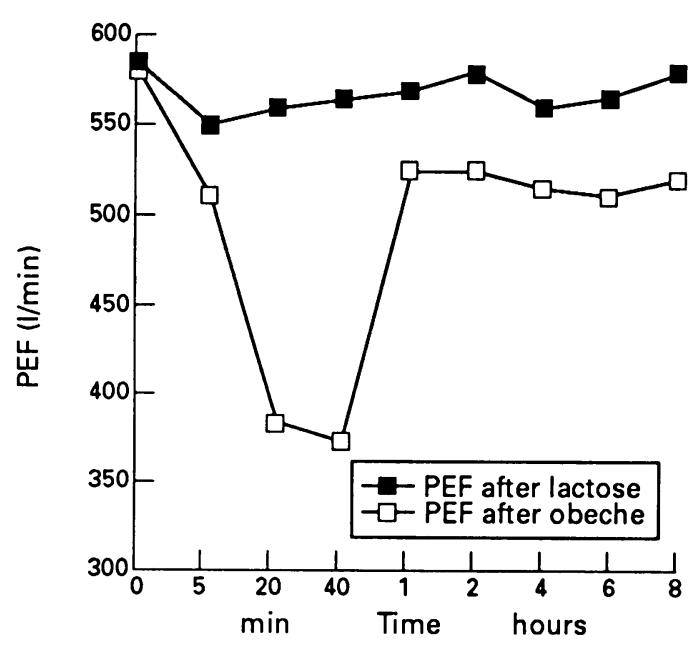

Figure 2 Peak expiratory flow (PEF) values of patient 2 after obeche and lactose provocation tests. became asymptomatic and could continue to work.

\section{Discussion}

The immunological mechanisms of hypersensitivity to obeche are uncertain because the nature of obeche tree antigens has not been established. It is likely, however, that proteins found in the latex play a major part in triggering both antibody and cell mediated responses after antigen exposure in sensitised individuals. $^{2}$

Both patients in this report had a history of atopic dermatitis and both smoked regularly. According to recent literature there is an increased risk among atopic individuals for developing occupational asthma. ${ }^{4}$ Smoking, which is associated with an increased total serum IgE, is another risk factor. ${ }^{45}$

Non-specific bronchial hyperresponsiveness was not a predisposing host factor in the development of red cedar asthma. ${ }^{6}$ In the present study, one patient had non-specific bronchial hyperresponsiveness and the other did not. Nasal symptoms, on the other hand, can appear as an early sign of occupational asthma. ${ }^{46}$ According to earlier studies rhinorrhoea and conjunctival symptoms are early signs of work related exposure which occurred in both patients in the present study.

1 Hinojosa M, Moneo I, Dominguez J, Delgado E, Losada E, Alcover R. Asthma caused by African maple (Triplochiton scleroxylon) wood dust. I Allergy Clin Immunol 1984;74:782-6.

2 Goldsmith DF, Shy CM. Respiratory health effects from occupational exposure to wood dusts. Scand $f$ Work Environ Health 1988;14:1-15.

3 Salorinne Y. Single-breath pulmonary diffusing capacity. Reference values and application in connective tissue diseases and in various lung diseases. Scand $\mathcal{f}$ Respir Dis 1976; Suppl 96

4 Venables KM, Tee R, Hawkins E, Gordon DJ, Wale CJ, Farrer NM, et al. Laboratory animal allergy in a pharmaceutical company. Br f Ind Med 1988;45:660-6.

5 Zetterman O, Osterman K, Machado L, Johansson SG. Another smoking hazard: raised serum IgE concentration and increased risk of occupational allergy. BMF and increased

6 Chang-Yeung $M$, Desjardins A. Bronchial hyperresponsiveness and level of exposure in occupational asthma due to western red cedar (Thuja plicata). Am Rev Respir Dis 1992;146:1606-9. 